\title{
Tobacco use among Indian states: Key findings from the latest demographic health survey 2019-2020
}

\author{
Balram Rai', Mahadev Bramhankar ${ }^{1}$
}

\section{Dear Editor,}

Tobacco use is associated with accelerated mortality among adults especially in low- and middle-income countries, where the burden of tobacco-related illness and death is heaviest ${ }^{1}$. More than 1 million adults die each year in India due to tobacco use accounting for $9.5 \%$ of overall deaths ${ }^{2}$. India faces a dual burden of tobacco use in the form of smoking and smokeless tobacco. According to the Global Adult Tobacco Survey (GATS) conducted in 2016-17, the overall prevalence of smoking tobacco use is $10.38 \%$ and smokeless tobacco use is $21.38 \%$ in India. Of all adults, $28.6 \%$ currently consume tobacco either in smoke or smokeless form, including $42.4 \%$ of men and $14.2 \%$ of women ${ }^{3}$. The Demographic Health Survey, known as the National Family Health Survey (NFHS) is one of the largest health surveys conducted in India providing disaggregate estimates of several health and demographic indicators. It has been a major source for planning policies and programs for different aspects of health among the Indian population. As NFHS and GATS are nationally representative household surveys using multistage sampling design with an overall response rate of $>90 \%$; they produce enough sample size for reliable estimates to be made, at least at state level, for comparison.

The government of India recently released the key findings from Phase 1 of the National Family Health Survey conducted in 2019-20, which also included information regarding current tobacco use among Indian adults in 22 states and union territories ${ }^{4}$. The results are compared with those of the GATS ${ }^{3}$ to track the progress in these Indian states (Table 1). Further, the results are stratified in terms of gender and place of residence (rural vs urban) to assess the heterogeneity of tobacco use among Indian adults. The prevalence of tobacco use among men has declined in most states, except Sikkim, Goa, Bihar, Gujarat, Himachal Pradesh, and Mizoram, where an upward trend can be seen. In the case of women, the prevalence has declined in almost all states except Mizoram and Sikkim. Tobacco use in north eastern states remains a challenge ${ }^{5}$, where prevalence is still quite high. The prevalence of tobacco use in rural areas is higher than in urban areas. The rural-urban divide in the prevalence of tobacco use can be clearly seen in the latest findings. The absolute number of tobacco users in India is still very high due to its huge population, which has a high risk for developing various chronic diseases. The tobacco control programs need more targeted interventions for specific groups in the population. Despite all cessation policies, people are still consuming tobacco in both forms in India. The tobacco users should be strongly encouraged to quit tobacco to eliminate longterm detrimental effects on their health. The decline in tobacco use definitely shows some positive signs for tobacco prevention and cessation programs in India, but it is yet far from achieving the goal of a tobacco-free India.
AFFILIATION

1 Department of Mathematical Demography and Statistics, International Institute for Population Sciences, Mumbai, India

CORRESPONDENCE TO Balram Rai. Department of Mathematical Demography and Statistics, International Institute for Population Sciences, Mumbai, Maharashtra 400088, India. E-mail: balramrai009@gmail.com ORCID ID: https://orcid.org/00000002-3987-2557

\section{KEYWORDS}

India, tobacco control, smokeless tobacco, tobacco use, NFHS

Received: 22 December 2020 Revised: 14 January 2021

Accepted: 15 January 2021 
Table 1. Prevalence (\%) of tobacco use among men and women aged $\geq 15$ years across the states of India

\begin{tabular}{|c|c|c|c|c|}
\hline \multirow[t]{2}{*}{ State } & \multicolumn{2}{|c|}{$\begin{array}{l}\text { NFHS-5 } \\
(2019-20)\end{array}$} & \multicolumn{2}{|c|}{$\begin{array}{c}\text { GATS } \\
(2016-17)\end{array}$} \\
\hline & Men & Women & Men & Women \\
\hline Andhra Pradesh & 22.6 & 3.8 & 30.0 & 10.1 \\
\hline Andaman and Nicobar Islands & 58.7 & 31.3 & NA & NA \\
\hline Assam & 51.8 & 22.1 & 62.9 & 32.9 \\
\hline Bihar & 48.8 & 5.0 & 43.4 & 6.9 \\
\hline $\begin{array}{l}\text { Dadra and Nagar Haveli, } \\
\text { Daman and Diu }\end{array}$ & 38.6 & 2.9 & NA & NA \\
\hline Goa & 18.2 & 2.6 & 15.3 & 4.0 \\
\hline Gujarat & 41.1 & 8.7 & 35.5 & 10.4 \\
\hline Himachal Pradesh & 32.3 & 1.7 & 30.4 & 1.7 \\
\hline Jammu and Kashmir & 38.3 & 3.6 & 39.7 & 6.2 \\
\hline Karnataka & 27.1 & 8.5 & 35.2 & 10.3 \\
\hline Kerala & 16.9 & 2.2 & 23.0 & 3.6 \\
\hline Ladakh & 35.7 & 3.2 & NA & NA \\
\hline Lakshadweep & 28.5 & 17.5 & NA & NA \\
\hline Maharashtra & 33.8 & 10.9 & 35.5 & 17.1 \\
\hline Manipur & 58.1 & 43.1 & 62.5 & 47.8 \\
\hline Meghalaya & 57.7 & 28.2 & 59.8 & 34.2 \\
\hline Mizoram & 72.9 & 61.6 & 64.9 & 52.4 \\
\hline Nagaland & 48.4 & 13.7 & 54.2 & 31.7 \\
\hline Sikkim & 41.3 & 11.7 & 26.4 & 8.4 \\
\hline Telangana & 22.3 & 5.6 & 25.9 & 9.8 \\
\hline Tripura & 56.9 & 50.4 & 67.5 & 61.4 \\
\hline West Bengal & 48.1 & 10.8 & 48.5 & 17.9 \\
\hline
\end{tabular}

NA: no available data.

\section{REFERENCES}

1. World Health Organization. Tobacco. https://www.who. int/news-room/fact-sheets/detail/tobacco. Published May 27, 2020. Accessed December 20, 2020.

2. World Health Organization, Regional Office for SouthEast Asia. WHO Factsheet 2018, India. https://apps.who. int/iris/bitstream/handle/10665/272672/wntd_2018_ india_fs.pdf?sequence=1\&isAllowed $=y$. Published 2018 . Accessed 20 December, 2020.

3. Mumbai and Ministry of Health and Family Welfare, Government of India, World Health Organization, Centers for Disease Control and Prevention, Tata Institute of Social Sciences. GATS 2: Global Adult Tobacco Survey - India 2016-17. https://www.who.int/tobacco/surveillance/ survey/gats/GATS_India_2016-17_FactSheet.pdf. Accessed December 20, 2020.

4. Ministry of Health and Family Welfare, Government of India, International lnstitute for Population Sciences. Fact Sheets, Key Indicators 22 STATE,S,/UTs FROM PHASE .
I: National Family Health Survey (NFHS-5) 2019-2020. http://rchiips.org/NFHS/NFHS-5_FCTS/NFHS-5\%20 State $\% 20$ Factsheet $\% 20$ Compendium_Phase-I.pdf. Accessed December 15, 2020.

5. Ladusingh L, Dhillon P, Narzary P. Why do the youths in Northeast India use tobacco?. J Environ Public Health. 2017;2017:1391253. doi:10.1155/2017/1391253

\section{CONFLICTS OF INTEREST}

The authors have completed and submitted the ICMJE Form for Disclosure of Potential Conflicts of Interest and none was reported.

\section{FUNDING}

There was no source of funding for this research.

PROVENANCE AND PEER REVIEW

Not commissioned; internally peer reviewed. 